\title{
BEYOND MIRRORS: LAWRENCE FRIEDMAN'S MOVING PICTURES
}

\author{
AVIAM SOIFER \\ "L'exactitude ce n'est pas la vérité." \\ Henri Matisse, quoted in \\ Robertson Davies, What's \\ Bred in the Bone 334 (New \\ York, 1985) \\ "[A] legal system . . . accommodates the equally exigent de- \\ mands of being and meaning . . . in a universe in which what a \\ thing does is only one of the things that it means, but every- \\ thing that it means is something else that it does." \\ Arthur Leff, "Law and ...," \\ 87 Yale Law Journal 989 (1978)
}

Lawrence Friedman is a rare and remarkable phenomenon. $\mathrm{He}$ is a counter who thinks and a thinker who counts. He is aware of paradoxes such as the fact that "Everybody is an individual; everybody is also a conformist" (1985b: 102). More specifically, Friedman is particularly knowledgeable about the limitations and unpredictable consequences of efforts at legal reform. Yet, surprisingly, he seems somehow to be able to escape transforming his healthy skepticism into cynicism.

A list of Lawrence Friedman's publications would exhaust a large chunk of my word limit. But such a list would serve an important function. It would suggest the range of Friedman's scholarly interests as well as his astonishing productivity. Even the titles of Friedman's articles and books belie a curious but prevalent notion that Friedman leads an apocryphal band of reductionistfunctionalist-instrumentalists. There is a good deal of talk, and a fair amount of scholarly critique published, attacking a group of legal historians who ignore or deny the idea that legal categories of thought have impact on society or that there are particularistic,

This essay was completed in the Fall of 1987. It is Lawrence Friedman's way to have published a half dozen or so articles since then, too late to be included in this discussion. The author thanks Daniel Offner for his research assistance and Kathy Abrams, Mary Dudziak, Chip Lupu, Martha Minow, David Seipp, Josephine Woll, Larry Yackle and, most particularly, Lance Cassak and Carol Weisbrod for reading drafts and discussing Lawrence Friedman's work with me.

LAW \& SOCIETY REVIEW, Volume 22, Number 5 (1988) 
changeable qualities in legal culture (Gordon, 1987; Vandevelde, 1980).

Yet in nearly-forgotten 1960s classics, for example, Friedman introduced theoretical categories and perceptive analysis concerning law reform and legal culture to legal history scholarship. He led discussion of how legal institutions "have a definite role, rather poorly understood, as instruments that set off, monitor, or otherwise regulate the fact or pace of social change (1969a: 29). ${ }^{1}$ With his characteristic concern for the kinetic quality of law, Friedman provided important insights about desuetude, legalistic reasoning, and the many constraints on judicial discretion.

Critics tend to ignore Friedman's leadership on issues of methodology, theories of change, and questions of whether law follows, leads, or mirrors society. Friedman is hardly the simple and pure instrumentalist some describe.

To attempt to catch up only with what Friedman has done for us lately-e.g., a book on the legal issues of age discrimination and mandatory retirement; another on the tendency toward total justice and plural equality in the twentieth century; a chapter on changing legal consciousness concerning the rights of schoolchildren; a massive revision and expansion of his single-volume history of American law; articles on diverse additional subjects including, uncharacteristically, one that invades the turf of constitutional law (1984a, 1984c, 1985b, 1986; Friedman et al., 1987)-suggests the enormous breadth of Friedman's careful, lucid, and adventurous scholarly achievements.

There can be little doubt that Friedman's work on the penetration of social, economic, and political factors into legal thought-and his less well known and, to be sure, his lesser emphasis on the reverse phenomenon-constitutes a remarkable, pioneering scholarly accomplishment. Today, however, there is significant controversy about Friedman's oeuvre overall. That controversy raises several questions worth pondering. Is Friedman's work appreciated as it should be? Why does he feel targeted in generational combat as one of "the dragons that need killing?"

1 See, for example, Friedman's many articles in the 1960s discussing the relative power of legal ideas such as "Law Reform in Historical Perspective," 13 St. Louis Law Review 351 (1969); "Legal Culture and Social Development", 4 Law \& Society Review 29 (1969); "Legal Rules and the Process of Social Change," 19 Stanford Law Review 786 (1967); with Ladinsky, "Social Change and the Law of Industrial Accidents", 67 Columbia Law Review 50 (1967); "On Legalistic Reasoning-A Footnote to Weber," 1966 Wisconsin Law Review 148. See also Friedman's discussion of the impact of legal ideas and the issue of legal change in his books of that period such as Contract Law in America: $A$ Social and Economic Case Study (Madison, 1965) and Government and Slum Housing: A Century of Frustration (Chicago, 1968) and his chapters "Social Change Through Law" in Law and Society: An Introduction (Englewood Cliffs, N.J., 1977), and "Social Change and Legal Change" in The Legal System (New York, 1975). 
(1984c: 573) And where does Friedman stand on the continuum of debate about the relative autonomy of law?

Throughout his work, on both micro- and macro-levels, Friedman has raised unanswered questions in regard to popular assumptions concerning historical causation. He has produced devastating critiques of formalistic approaches to legal history. Moreover, Friedman's descriptions of legal matters are peppered with vivid contextual details and with recognizable, unexceptional folks. Yet Friedman is the legal historian who deserves credit for introducing important Weberian notions long ago as well as for offering a sensitive critique of them. His work has demonstrated, early and often, that scholars have much to learn from a bottom-up approach to changes in legal ideas, as compared to more traditional tracking of doctrinal change in appellate opinions and treatises.

In a sense, Friedman can be considered the last of the real legal realists. But he also follows Willard Hurst as one of the first and few legal realist historians. ${ }^{2}$ In emphasizing the dynamic quality of legal ideas, Friedman adapted and moved beyond Hurst's work. As does Hurst, whom Friedman described as "this greatest of legal historians [who] was not interested in law as such, but rather in what it did to, for, or against the rest of us" (1984c: 566), Friedman emphasizes factors outside the doctrinal law box. ${ }^{3}$ Indeed, he directs witticisms at those who create fancy theories from appellate decisions. Friedman describes law libraries as less hard on the allergies than the down-and-dirty stuff of county court records and the like. Although he has been careful not to deny the symbolic aspect of law, Friedman concentrates on clashing interests; he finds law in corporate personnel policies, trial courts, and the hallways outside the courtrooms.

So why, one might ask, is Lawrence Friedman so alienated from the legal historians who work under the umbrella of critical legal studies? And why does his emphasis on competing interests as the moving force behind legal change not seem to appeal to the law-and-economics crowd? In this essay I suggest that Friedman is able to convey the problematic role of law-as-mirror with remark-

2 The legal realists themselves were generally not seriously interested in history, with the possible exception of Walter Nelles and the great efforts at sweeping categorization by Karl Llewellyn and, later, Grant Gilmore. See generally John Henry Schlegel "American Legal Realism and Empirical Social Science: From the Yale Experience" 28 Buffalo Law Review 3 (1981) and "American Legal Realism and Empirical Social Science: The Singular Case of Underhill Moore" 29 Buffalo Law Review 2 (1980); Laura Kalman, Legal Realism at Yale, 1927-1960 (1986).

3 For a most useful historiographic map delineating variations on the internal/external theme concerning how legal history has been done, see Robert Gordon, "J. Willard Hurst and the Common Law Tradition in American Legal Historiography," 10 Law \& Society Reviewo 9 (1975). See also Steve Diamond, "Legal Realism and Historial Method: J. Willard Hurst and American Legal History," 77 Michigan Law Reviewo 784 (1979); Calvin Woodard, "History, Legal History, and Legal Education," 53 Virginia Law Review 89 (1967). 
able clarity, even as he anticipates the distorting quality of reflection and its possible influence on conduct. Friedman's word-pictures constantly remind us that neither life nor law is static, try as we might to freeze the frames of our existence.

\section{THE IMPACT OF THE IDEAS OF A LAW PROFESSOR?}

It is paradoxical to write about the impact of any academic's ideas, but the tensions are exaggerated when the subject is Friedman. One dare not speak of progress, but writers of legal history generally have moved past the purportedly clearcut categories of the lawyers who replaced parsons as described in Perry Miller's work. We no longer seem eager for the neat symmetry that turned Talcott Parson's tables. Today there is a serious, sometimes bitter split. Some scholars are concerned with the complexity and importance of inquiry about how an average person feels law and deals with it. Others wish to explore the inherent contradictions in, and presumed legitimating functions of, mandarin legal texts and techniques (Trubek, 1984: 575; Whitford, 1986: 75).

Some of Friedman's critics suggest that Friedman and others of the Wisconsin school are unconcerned with the impact of ideas generally and with the valuable cover story provided by legal mythology specifically. In response, Friedman and his law-and-society cohorts tend to denigrate the attention lavished by abstract thinkers on legal epiphenomena. Moreover, they doubt that exposing contradictions in learned journals does much to advance any radical cause or significantly aids any recognizable left or liberal agenda. But the argument is about more than tactics; it may even be over more than the traditional shadowboxing in internecine warfare on the left.

Throughout his work, Friedman has emphasized that elements other than the rare flowers cultivated in the hothouses of academe are crucial to how we, and, far more important, how others not members of our small professional cliques, perceive law and legal change. Repeatedly, in forceful metaphors, Friedman argues that society-the puppeter-pulls the strings and law responds. Law may be a peculiar dialect, but social and economic forces create and develop the language for law's development. It is, therefore, somewhat Dadaist to pursue Friedman's influence through selections culled from his extraordinary scholarly output. And it seems more than a trifle absurdist to violate Friedman's own careful, skeptical canons concerning what is actually safe to say about causation or intellectual influence.

What follows is a paradoxical, Pirandellian search for an author and his character. I begin by suggesting why any portrait of Friedman as foremost practitioner of some dominant functionalist or instrumentalist school of legal history committed to determinism or swaddled in teleological faith is largely a caricature. In do- 
ing so, I will pursue how legal ideas reflect and help create social change, with particular attention to Friedman's famous proclamation in A History of American Law that his book "treats American law ... not as a kingdom unto itself, not as a set of rules and concepts, not as a province of lawyers alone, but as a mirror of society" (1985a: 12).

In surveying Friedman's contribution, I concentrate almost exclusively on the books Friedman has published in the past few years (1985b: 102; 1985a). (Even if Friedman did not write with extraordinary verve, and even if he did not combine his unusual clarity with a knack for uncovering memorable nuggets within the vast material he mines, news of Friedman's rate of scholarly output should obviously be kept from those who set salaries and grant tenure.) In the context of this "limited" sample of Friedman's work, I will consider competing notions of how mirrors function. ${ }^{4}$

Friedman is fascinated with change and with the problem of how the historian can detect it. $\mathrm{He}$ is also quite cautious about what we know and whether we have data to support how we know it. At the same time, he recently has explored ways in which deeply held, inconsistent, and frequently half-baked ideas about law reflect and also influence American culture and character.

Because of his abiding concern for the public, i.e., for what Everyperson believes about legal categories, whether she or he actually thinks about law or not, Friedman pays close attention to the audience for law. He rejects auteur theories of legal creation. Instead, he is fascinated with how feedback loops might work between society and the legal product. Friedman also manages to blend his wit and hard-bitten skepticism with social consciousness across a vast array of subjects. A central theme throughout Friedman's work is that law is shaped by the American public, but that law also has a lesser, but still significant, shaping effect on American life.

I will suggest in conclusion why it is appropriate to move beyond mirrors and metaphors to consider the Friedman phenomenon as some amazingly prolific, one-man major motion-picture studio. Friedman is most closely akin to Warner Brothers in the 1930s.

Warner Brothers' films generally managed to reflect changing popular ideology throughout the New Deal. In the process,

4 I do so with the deference due both the great Groucho-in-a-nightcap sequence in "Night at the Opera" and Lewis Carroll's Through the Looking Glass. But, as Alice says about the house on the other side of the looking glass (Martin Gardner, ed., The Annotated Alice (New York, 1960: 180-182)):

I can see all of it when I get upon a chair-all but the bit just behind the fireplace. Oh! I do wish I could see that bit! I want so much to know whether they've a fire in the winter; you never can tell, you know, unless our fire smokes, and then smoke comes up in that room too-but that may be only pretence, just to make it look as if they had a fire. 
Warner Brothers neither created a false need nor falsely filled a real need (Roddick, 1983: 8). As in the best social conscience films of the 1930s for which Warner Brothers is famous, Friedman's work subtly but unmistakably reflects an important critical stance. It also shows several different facets of an abiding social concern.

\section{MIRRORS AND MIRAGES}

Friedman's commitment to writing a book about law rather than a law book (Abel, 1973: 175; Trubek, 1984: 575) is even clearer than his own image of the mirror might suggest. He continues, "[This book] takes nothing as historical accident, nothing as autonomous, everything as relative and molded by economy and society. This is the theme of every chapter and verse" (1985a: 12). It is this attitude that seems to infuriate many scholars or, in an ironic argument in the alternative, to be dismissed as a commonplace everybody already knows. Friedman's pathbreaking is often ignored because the trails he blazed are now so heavily traveled. Though Friedman's mirror analogy and his denial of legal autonomy stirred considerable controversy when they were first postulated, today hardly anyone argues that law is entirely autonomous or, for that matter, that law never channels thought and action.

If we are candid, we must concede all legal history is done with mirrors. Today's historiographic debates concern how dark the glass is, whether there is in fact any "there" out there to be reflected, and what to make of the inevitable distortion caused by use of a mirror. In several senses, reflection is an inevitable part of the legal historian's craft. But there are mirrors and then there are mirrors. ${ }^{5}$ Moreover, what we seek tends to be what we get and may be all we can hope to see. So there is vigorous debate today among legal historians over the relative merits of contemplating a few navels or attending exclusively to mandarins. It is on issues such as these that Friedman often is caricatured (and sometimes sees himself) as an embattled, autumnal law-and-society archetype.

Friedman's work does not get the appreciation it deserves for several reasons. First, there is jealousy. Friedman is an exceptionally clear, compelling and prolific writer who seems to produce endless pages of luminous prose without the effort the rest of us require. The very fact that he writes so much about so many different topics also makes it difficult to pigeonhole Friedman. This,

5 It may be that "Hell is-other people" particularly when one relies on someone else as a looking glass. Jean-Paul Sartre, "No Exit" in No Exit and Three Other Plays (New York, 1955: 20-21, 47). Moreover, as the adolescent who spends a great deal of time gazing at himself in mirrors tells his father in Peter Taylor's wonderful short story, "Promise of Rain": "[E]ven among mirrors there's a difference! Especially the big ones. They all give you different ideas of how you look." (Peter Taylor, The Old Forest and Other Tales (New York, 1985: 95). Cf. Richard Rorty, Philosophy and the Mirror of Nature (Princeton, 1979)). 
in turn, frustrates our need for order as well as our desire to have time for things other than keeping up with the literature current in our professional fields. Next, because he often seeks and sometimes even finds an audience of nonspecialists, Friedman is derided as a popularizer and a mere synthesizer. Moreover, in a paradoxical bit of generational combat, Friedman is attacked by younger scholars both for lack of methodological sophistication and for insistence on methodological care. Friedman is said by some to be overly optimistic about incremental change while others find him overly dubious if not cynical concerning the possibilities of radical change.

To me what is most striking about Friedman's work, however, is the extent to which he has successfully moved beyond the traditional debates between idealists and materialists, intellectual historians and social historians. To a remarkable extent, Friedman's work already achieves what Wood (1979: 27) has argued is needed to meet the challenge of "nothing less than a revolution in our history-writing" (1979). Wood calls for "[A] kind of zoom lens that will enable us to move easily back and forth from the small, closeup world of unique events and individual volition where men try to use ideas for their own particular purposes to the larger aggregate and deterministic world of cultural conventions and collective mentalities where ideas control men" (1979: 37).

Friedman moves with confidence and clarity between memorable descriptions of actual people entangled in litigation and massive studies of what can be gleaned from litigation statistics over many decades. He interweaves humanistic and social science strands into vivid prose, often employing earthy imagery or flashes of wit premised on ironic insights. Jars of applesauce, for example, illustrate Friedman's points about safety regulation; our appetite for chickens illustrates the problematic issue of the demand and supply for legal resolutions.

What particularly distinguishes his work, however, is the extent to which it successfully anticipates the important historiographic point recently made by David Hall. In considering the overlapping worlds of print culture and collective mentality in seventeenth century New England, for example, and in an essay reviewing recent historical work on the New England Puritans, Hall points out that words and ideas mattered even to the unlettered laity. There were "affective, aesthetic, and ritual dimensions" to the multi-layered discourse of Puritanism as understood by both ministers and laity (Hall, 1987: 222). Hall notes that the newer historical work has "a new confidence in language, together with an understanding of language itself as essentially symbolic" (1979: 166).

This powerful point about Puritanism is, if anything, even more powerful in the context of American legal history. The common sense of Americans not trained in law includes important assumptions about what law will or will not, should or should not be. 
Obviously, lawyers and judges constantly address and appeal to the perceptions of their lay audiences, albeit in varying degrees and in differing contexts. Those with legal training occasionally attempt to change common understandings of law, to be sure, but important legal disputes still echo the nursery cry, "Not fair" (Milsom, 1982: 272).

In fact, it is Friedman's concern for what the general population considers fair or not fair that sets his work apart from those who focus on legal doctrine. He emphasizes society and de-emphasizes the clout of the legal elite, bridging what has seemed an almost unbridgeable gulf between the two competing ideas as to which ideas count. Indeed, as Wood and Hall suggest, and as recent attempts to incorporate perceptions from anthropology and popular culture indicate, the gulf may be narrowing. Friedman's insistence on the many contributions to our understanding of community-structured legal life is part of that process.

It is difficult to pin down and criticize Friedman, as it is to criticize Maitland, in part "because of the caution with which he formulated his answers, a caution not at first apparent in the transparent lucidity of his style." It is also fair to say of Friedman that, as with Maitland, "[i]t is virtually impossible to be bored ... even at his most technical, and seeing how very boring even good historians can be this gives him a remarkable advantage" (Elton, 1985: 35). Friedman is similarly able to convey "what lies concealed within the hard rind of legal history . . . the best, often the only evidence we have for social and economic history, for the history of morality, for the history of practical religion"6 (Maitland, 1911: 485). Unlike Holmes and others who make a fetish either of constructing or demolishing doctrinal categories, Friedman has a social theory of law in which society plays a leading role. People peer out from behind the law he discusses.

Friedman echoes Maitland in other respects as well. (It may be more than mere coincidence that Friedman's first historical work in the 1950s was on English legal history, a realm in which "the further back one went, the more one found law connected to social structure, economic organization, agricultural method, administrative practice, currents of religious and philosophical specu-

6 F.W. Maitland, 3 Collected Papers 485 (H.A.L. Fisher, ed. 1911). It may be more than coincidence that Friedman was attracted to English Legal History and got an L.L.M. in that subject from the University of Chicago in 1953. Before the contributions of William Hurst, and of his successors such as Lawrence Friedman and Harry Scheiber, "the further back one went, the more one found law connected to social structure, economic organization, agricultural method, administrative practice, currents of religious and philosophical speculation. The great researchers of the classical period and their successors had given medieval law a context. But as one approached more recent times, legal history started to thin out to the distinctly 'legal' again, and explanations for the shape of legal things to revert to the genetic." Gordon, supra note 3, at 21. 
lation"7 (Gordon, 1975: 21)). As with Maitland, there is "the directness with which he speaks to you through the printed page" (Milsom, 1982: 270) and the important sense in which he is able to "feel some sympathy for both sides" (Ibid.: 271) in the real or imaginary conflicts that lead people to legal entanglement. Most crucially, however, and perhaps more than even the great Maitland, Friedman has a remarkable "sense for common feelings" (Ibid.: 281). He maintains an outsider's perspective but is not condescending about the people whose worlds are reflected in the legal detritus he probes. Indeed, "the visions he communicates with such power are of people whose situation he sees so clearly that he feels their feeling." (Ibid.: 270). And Friedman discusses their messy interlocking worlds with considerable humor and flair.

\section{A. Total Justice: "An Epic Tale of Loss and Gain"}

Overall, Total Justice serves as a fine example of Friedman's clear, insightful, and provocative work (1985b). It is an exploration of a theory of change in American legal culture, moving from acceptance of the harsh uncertainty of life in the nineteenth century toward demands for legal remedies for greatly expanded categories of injuries or rights in the twentieth century. As always, Friedman emphasizes the impact of social change on legal change rather than the reverse. But his argument is anything but simple-minded determinism. ${ }^{8} \mathrm{He}$ insists, for example, that the choice of which particular tort doctrines prevailed out of the vast array available was neither primarily a product of the "taught tradition" Roscoe Pound emphasized, nor was the evolution of tort doctrine " inevitable' in a strict sense or 'determined' in every detail by economic needs; least of all does it mean that the class solidarity of judges shaped [tort doctrine] in a conscious way" (Ibid.: 56). Friedman suggests instead that the mentality of boosterism prevalent in nineteenth-century America was primarily responsible. An expanding, industrializing nation, in which sudden death and serious injury remained commonplace, got the tort law it seemed to want.

7 It happens that Charles Beard also did his first work, and his doctoral thesis based on county histories and records, on "The Office of the Justice of the Peace in England: In Its Origin and Development," Ellen Nore, Charles $A$. Beard: An Intellectual Biography 18 (Southern Illinois University Press, 1983).

8 Starting with his earliest work, Friedman has accepted the idea that legal ideas sometimes influence conduct, although his emphasis has always been on the much greater influence of conduct on legal ideas. His disagreement with those who today pursue the "relative autonomy of law" is not with use of the concept itself but rather with where on the autonomy scale law should be placed. (It is a given, after all, that relatives are not autonomous.) See, e.g., Friedman, 1984a: 572-74 ("It is one thing to say that law is not merely instrumental; it is quite another to behave or write as if it is not instrumental at all, or as if its instrumental features do not matter as much as the rest of its work"); Friedman, 1985b: 28 ("Every scholar worth his salt would agree that the legal system has some autonomy; the question is, how much?"). 
Total Justice is full of insights ("lawyers both prevent redress and promote excessive redress" (Ibid.: 23); "[a] safety net encourages some people to swing on the trapeze, or walk the tight-rope, who would otherwise not dare" (Ibid.: 105) and strange-but-true concrete examples: liberality in workmen's compensation is illustrated with the case of an employee who prevails after being hurt while urinating from a moving truck; the persistence of moral and religious notions enforced by law is illustrated by a 1921 Maine Supreme Court decision upholding a conviction for blasphemy. Moreover, to oversimplify a richly textured argument, Friedman makes a powerful case that our current legal culture is composed of fewer "zones of immunity" (Ibid.: 82) protecting the discretion of government officials and civil defendants than it was in the nineteenth century. Instead, we have increased expectations for redress for a vast range of harms. But Friedman is careful to consider a counterexample-an increase in the delegalization of attitudes toward sexual conduct-and weaves that story into his rather sweeping general assessment of how "attitudes become processes and processes become institutions" (Ibid.: 148). Altered legal consciousness and changes in legal culture, Friedman suggests, do create tendencies to "bend toward the norm, like plants bending and growing toward the light" (Ibid.: 67).

It might appear that in Total Justice Friedman is responding to those who have criticized his emphasis on how social norms control law. This book emphasizes more than any of his earlier work what Friedman rather abstractly refers to as the effect of an "upward spiral" of alterations in social norms. But Friedman actually has long acknowledged the symbolic function of law and has taken into consideration what we have come to call the relative autonomy of legal ideas a focus of his work in the 1960s.

More significantly, Friedman continues to look for explanations. He tests his emphasis on the control of social forces over law by wrestling with legal categories in which, at least at first glance, it seems extremely difficult if not impossible to explain why some rules rather than others prevail. Friedman makes the point that it is difficult to tell who benefits from certain commercial law arrangements rather than others, for example. ${ }^{9} \mathrm{He}$ also

9 "It is doubtful that majestic capitalism would have smothered in its crib without the rule of caveat emptor. It is doubtful whether specific doctrines of commercial law were cause, effect, or condition of American capitalism; or all or none of these." History of American Law, p. 264. As Gordon notes, in this respect-as in many others-Friedman does not fit the paradigm of the dominant vision of legal history, which Gordon terms evolutionary functionalism (36 Stanford Law Review 57, 76, n. 47). See also, e.g., Friedman and Macaulay agree with disengagement theory of autonomous law, positing that there is "law of leftovers," id., p. 89, n. 79; Friedman shows in family law context that legal enactment may not have effect, since it merely ratifies social relationship already crystallized, $i d$., p. 91, n. 83; Friedman as an example of the "marvelous work" using a cultural anthropology approach, id., p. 95, n. 89. All these footnotes make Friedman sound like a creative CLS type. But if it is not 
recognizes that for every social trend there seems to be a countertrend (Friedman, 1985a as criticized by Tushnet 1977: 81; Friedman 1985b: 151). But generally Friedman sustains a rather sobering, and certainly humbling, argument that neither social engineering nor impressive theorizing is likely to cause major changes, unless external social factors are ripe for change.

Indeed, Friedman seems preoccupied by issues of legal change. He is unquestionably a worthy successor to Hurst, but Friedman seems less inclined than Hurst to accept consensus, inertia, and drift as dominant social forces. Perhaps as part of his own generational revolt, Friedman constantly stresses the dynamic quality of both social life and law. He perceives the world as somewhat akin to a beehive of activity, its action primarily competitive and chaotic, rather than harmonious and steady. Friedman does not sacrifice realism for resolution.

\section{B. Your Time Will Come: The Law of Age Discrimination and Mandatory Retirement- "And You Won't Have Everything!"}

To his credit, Friedman does not shy away from difficult tests for his hypotheses on the dominant role played by competing interests in changing the legal world. For example, in his book on the federal Age Discrimination Act of 1975-an act passed by Congress "in a fit of absentmindedness (perhaps)" (1984a: 16)-Friedman contends with a legal infant copied from a civil rights prototype. The Age Discrimination Act passed without significant support from identifiable pressure groups. In discussing this, as well as a 1967 Act that banned some additional forms of age discrimination in employment, Friedman points out that statutes often serve as surrogates for other, more deeply contested interests. Friedman speculates that concern over age discrimination is "a double stand-in." It approximates what he considers two important, albeit also largely unrecognized principles: the first is the civil rights principle, which attacks the use of any criterion considered to be unfair; the second is the tenure principle, which seeks to protect expectations developed over time.

Friedman is quick to point out that these two principles are largely unexamined and at least sometimes inconsistent. They are only half-conscious norms. Yet, as usual, the categories Friedman introduces provide useful scaffolding for organizing our thoughts. He distinguishes between unfairness, which is "not against the law, at least in so many words" and discrimination, "which is" (Ibid.: 48). Moreover, Friedman notes the symbolic function of antidiscrimination laws, but he suggests that it is patterns of conduct that

Friedman, then who is the target-the evolutionary functionalist-against which critical legal histories are to be arrayed? 
provide both crucial evidence and crucial targets for Draconian legal change.

Friedman is again trailblazing in his attention to issues of age discrimination, his collection and vivid description of concrete examples, and his attempt to reach an audience beyond the law school professorate. Ultimately, however, in this book the somewhat abstract nature of the two categories he employs, coupled with the open-ended quality of the stand-in notion, seem less well grounded than does most of Friedman's work. Nonetheless, Friedman clearly advocates the use of law to help change consciousness, since "[i]n justice, as society defines it, is also a cost" and since "the sense of right has been a powerful motor force" (Ibid.: 52-54). "The source of all law is the normative climate," according to Friedman, but it is vital to recognize that "law crystallizes and formalizes lumpy or ghostly feelings, adrift in society; it hardens them into definite shapes; and it sets up machinery that people can use, to translate feelings into action" (Ibid.: 54, 66).

\section{The Roots of Justice: Crime and Punishment in Alameda County, California, 1870-1910_"Just the Facts, Ma'am"}

To be sure, some parts of Friedman's scholarly output-particularly the study of criminal records in Alameda County, California, he co-authored with Robert Percival-are so studiously grounded in minute factual detail about the machinery of law that at first glance they seem to cry out for more theory. Theory lurks in all historic writing, of course, but The Roots of Justice may contain too much data and too little explicit interpretation for readers who crave clear narrative development, if not fancy overarching theory. But the book is unquestionably a significant historical contribution, and it shows Friedman is not blinded by teleological faith.

Despite important variations in plea bargaining rates and approaches to guilty pleas in the period covered by the study, and despite other, more minor changes, the class structure behind the three-tiered criminal system a century ago in Alameda County seems distressingly similar to the modern criminal law system Friedman and Percival describe there today. We still use the formal criminal law process in diverse ways, depending on whether we employ it to process misfits; to administer punishments, for the most part without jury trials, for more serious offenses; or to perform an educative function in the most sensational cases in which lawyers dominate the process and we compose and broadcast the official rules about what process is due. We still rely on the police to help distinguish among these three categories, as well as to operate a fourth level of discretionary justice (Friedman and Perci- 
val, 1981: 315). ${ }^{10}$ If anything, the storyline in Roots of Justice lacks reassuring movement. Neither clear progress nor clear regress leaps out at the reader. The central point the authors make, however, is that even low-visibility categories of legal culture are brimming over with so many variables as to make nice, neat generalizations impossible.

The Roots of Justice is rich in suggestive details. Its numerous tables include data ranging from arrests broken down by nationality and age group to less obvious categories such as the number of days between conviction and sentencing, broken down in terms of types of offenses and status of attorneys involved, and the percentages of total arrests for each offense class by time of day. We learn the ethnicity, gender, age, and occupation of those arrested for a number of different crime categories, that the successful prosecution of a typical license case actually cost Oakland more than seventy dollars in 1879, and even the number of arrests per police officer and per population.

Further, the monumental task involved simply in gathering the data for this study, with its relatively small yield of drama or glittering generalities, helps to underscore why few have heeded Friedman's perennial call to do the gritty work of digging out the "kilo-Ph.Ds" buried in every county courthouse. Yet despite his failure to win converts, Friedman remains not only remarkably versatile in his own legal history research, but unusually generous in his collaborations and in providing honorable mention to those who build theories, produce biographies, or otherwise toil throughout legal history's many rooms.

The glaring exception to Friedman's general generosity of spirit, beyond the occasional barbs he aims at what he considers the overly abstract meanderings of critical legal studies and the overly simple conceptualism of law and economics, is Friedman's general disdain for constitutional law. In this, he is undoubtedly

10 After Friedman and Percival published some of their preliminary data in "A Tale of Two Courts: Litigation in Alameda and San Benito Counties," 10 Law \& Society Review 267 (1976), Richard Lempert wrote a lengthy article reanalyzing their data, controlling for adult population. Richard Lempert, "More Tales of Two Courts: Exploring Changes in the 'Dispute Settlement Function' of Trial Courts," 13 Law \& Society Review 91 (1978). Lempert made the important point that paying attention to cases filed may miss an entire range of disputes that never made it to court in the first place. This point is not entirely lost on Friedman and Percival. And, as Lempert acknowledges, it is easy to criticize any collection of data for not collecting more or something else. Even the massive detail supplied by Friedman and Percival may be merely the tip of a peculiar iceberg, though they do an impressive job of supplementing their statistics with information culled from newspaper reports and other less obvious sources of social history as well. As Friedman once put it, "Reported cases, then, are always (or almost always) the tip of some sort of iceberg. That may be fine; after all ... the bottom of an iceberg may be much like the top, that is, essentially ice. Reported cases, on the other hand, may or may not tell us much about unreported cases or ordinary complaints. . ." (Friedman, 1984a: 47). 
true to the legal realist tradition (White, 1986: 452; Schlegel, 1984: 407-408; Llewellyn, 1934). In my view as a constitutional law teacher, Friedman here is too narrow-minded. Moreover, he contradicts his basic view that constitutional debate consists of poking away at "a kind of living fossil, the last and most vigorous survivor of conceptual jurisprudence" (Friedman, 1984c: 569), with his own constitutional insights in his magisterial $A$ History of American Law. In his recent work, Friedman shows definite signs of dawning enlightenment concerning the worthiness of constitutional issues for serious consideration (1986: 1 ; 1985b).

\section{A History of American Law: "They Said It Couldn't Be Done!"}

A History of American Law is that part of Friedman's work (so far) for which he is most likely to be recognized. If there are legal historians in one hundred years-and if they are not all simply ferreting about in the dust of thousands of county courthouses-they will have to come to grips with both the details provided and the sweeping story told in this remarkable book. Friedman was probably a bit disingenuous when he offered his book as a "whipping boy" and "a primer" (1985a: 10), but he was surely accurate when he suggested that the book would provide "a shape for the field, even if others find it misshapen" (Ibid.). When first published in 1973, this snappy single-volume account provided marvelous, memorable, and detailed examples of the numerous ways in which American law was never immanent and hardly static. $^{11}$

The enormous size, and considerable clout, of the landed middle class is the central thread in Friedman's impressively nuanced book. Friedman calls this "the master fact of American law and life" (1985a: 212). Perhaps it takes a mid-westerner fully to appreciate the phenomenon. This may help explain why a place such as Wisconsin nurtured the Hurst-Friedman school of legal history, with roots stretching directly back to populist historians such as

11 The first edition received generally euphoric reviews, see, e.g., W. E. Nelson, 18 American Journal of Legal History 182; H. A. Johnson, 23 De Paul Law Review 1086; E. D. Tucker, 86 Harvard Law Review 1625; W. A. Hill, 50 N. D. L. Review 147; S. J. Spitz, 36 Ohio S. L. J. 376; J. Lurie, 27 Rutgers Law Review 354; E. F. Murphy, 26 Stanford Law Review 701; C. A. Pierce, 42 Tenn. Law Review 615; J. H. Smith, 24 University of Toronto Law Journal 108; G. E. White, 59 Vinginia Law Review 1130; J. W. Ely; Jr., 26 Vand. Law Review, a 'few balanced critiques'; S. B. Presser, 122 University of Pennsylvania Law Review 217; and L. J. Mazor, 60 Minnesota Law Review 147 and Mark Tushnet's "wonderfully, or awfully (take your pick), foul-tempered review," John Henry Schlegel, "Notes Toward an Intimate, Opinionated, and Affectionate History of the Conference on Critical Legal Studies," 36 Stanford Law Review 391, 408, discussing Mark Tushnet, "Perspectives on the Development of American Law: A Critical Review of Friedman's A History of American Law," 1977 Wisconsin Law Review 81. Thus far, the second edition has had less attention and more praise, see, e.g., Calvin Woodard in N.Y. Times, Feb. 16, 1986, sec. VIII, p. 31. 
Thorstein Veblen, Vernon Parrington, and, most significantly, Charles Beard. Life in the land of the Northwest Ordinance may go a long way toward immunizing historians against coastal neuroses. They are alerted to the power and the persistence of the great American Middle Class.

A Chicagoan only belatedly transplanted to America's dreamland, California, Friedman demonstrates across a range of legal subjects that middle-class dominance never was secure. In fact, if his book has a single central subtext, it is movement. Legal arrangements are seldom settled. The winners in legal contests are anything but permanently ascendant. This is a crucial aspect of Friedman's approach, an aspect that illuminates a great deal about his general approach to legal history.

Friedman does not merely show snapshots. The metaphor of moving pictures is more appropriate. Friedman explains why he thinks, or perhaps hopes, that intrumentalism in the long run is the enemy of what he calls "vertical pluralism," which is a concept close to what some of his critics would discuss in terms of hegemonic hierarchy, ${ }^{12}$ provides a good illustration (1984a: 664). Reviewing what he has said about the nineteenth century, the period in which he has done most of his work, Friedman discusses "mobility for the few and dreams for the many" (Ibid.: 665). He writes in curmudgeonly language of a combination of factors that "acted as a brake on demands for redistribution of the social product" (Ibid.). But he also points out that the frontier was not the only safety valve: "there was also the hope of success, the culture and cult of opportunity," a metaphoric lottery for which tickets were hawked "on every corner, in every town" (Ibid.).

Friedman devotes attention throughout this book to those people he labels "The Underdogs" and to other victims of ascendant interests. Consistent with much of the rest of his scholarship, he reminds his readers of who got put down or kept down, even as he goes about the business of mapping how the law generally reflected hard-edged competition. It is also characteristic of Friedman to have raised doubts about the purportedly progressive motivation behind the Married Women's Property Acts, for example, before the recent outpouring of attention to the subject, but subsequently to have cited the new work and not his own original contribution. ${ }^{13}$

12 See $A$ History of American Law, 2d ed., p. 574 for a limited discussion of the issue.

13 In "Law Reform in Historical Perspective," 13 St. Louis Law Review 351, 362-363 (1969), Friedman used Married Women's Property Acts as an example of a "hidden ratification," explainable neither in terms of a quiet yet significant revolution suggested by the bare legal record nor in terms of a response to pent-up social and economic pressure. He credited the unpublished thesis of Ellen Thurman, as well as the compilation of family law statutes in 3 Vernier, American Family Law 166 ff. (1935). Though Friedman makes no mention of the issue in the first edition of A History of American Law, he 
In his recent work, Friedman often points out explicitly that cost-benefit analysis celebrating efficiency tends to omit unquantifiable, yet crucial, social costs. Ironically, this legal historian, seemingly so committed to hard data and empiricism, often appears to distrust profoundly the results of the marketplace. He refuses to accept the normative power of either the actual or the actuarial.

The irony may be resolved if we consider Friedman's empathy with those denied a fair place in the race of life and his sensitivity to the problematic nature of feedback loops. ${ }^{14}$ For Friedman, law is a part of the cult of opportunity. But belief in the revolutionary power of law, or in the power of de-mystifying law, is belief in a flickering, chimerical image. What Roddick said of the Hollywood studios in the 1930s might be said about the legal system as well (1983: 11):

The trends and events of public life provided the story material for and therefore strongly influenced the output of Hollywood; in turn, the image of themselves which the movies reflected back to the movie-going public exercised an influence on the same trends and events which had given birth to the image.

Friedman's work suggests that legal culture is similarly part of a circular relationship. There are obvious ideological overtones, but the perpetual loop depends on gauging and responding to audience needs in a sense that is largely manipulative, but also occasionally productive of an important focus for social consciences or even achievements. Like a great film such as The Maltese Falcon, A History of American Law has something for everyone: twists and turns in the plot, memorable characters, illuminating humorous moments, and vivid details that keep the viewer entranced. Both also respond to some of our deepest myths about individualism and society. And like Sam Spade, Friedman is hard-nosed and apparently beyond the fray. But his world-weary pose turns out to be just a pose when the crunch comes. He does the down and dirty work, but he also knows how to lead, perhaps even to inspire.

\section{HOW DOES IT ALL COME OUT?}

A major element in the criticism of Friedman's work involves dismay at his optimism. Friedman admits that he is in favor of gains, even symbolic gains, against discrimination. Indeed, he suggests, success may lie "precisely in the fact that the rules startle

cites generously to numerous recent studies in the $2 \mathrm{~d}$ edition, pp. 208-211, but not to his own 1969 article.

14 Even if "an exceedingly weak positive feedback loop" may be all that is necessary to explain the origin of life, T.F.H. Allen and Thomas B. Starr, Hierarchy: Perspectives for Ecological Complexity 49 (Chicago, 1982). Allen and Starr indicate the complexity of positive and negative feedback loops in the course of suggesting the importance of anticipation and purpose in "the evolved physical world [that] trades in futures." Id., p. 60. 
people" (1984a: 63). Friedman is a committed academic activist. His target, however, is more modest and almost certainly more realistic than the assault on paradigms favored by critical legal studies and by law and economics. Even Friedman's awareness of the folks who buy the tickets, his commitment to writing material that can be read by nonspecialists, appears to flow from a quiet zeal for reform.

Ironically, given the heat generated by the debate over what degree of relative autonomy one favors, Friedman quite clearly believes, as he has for a long time, that "[existing] structures of law and government, at least in the short run, exert a powerful influence on the way demands and attitudes become concrete" (1985b: 148). Additionally, he often expresses his willingness to accept inefficiency in exchange for gains in social justice (Ibid.: 151). He summarizes our legal culture's trend toward a total justice consciousness, a goal he notes can never be achieved, as follows: "I have to confess my personal sense of pleasure over many developments described. I like the spread of due process; I like the welfare state; I like justice for minorities; I like the broader meaning of equality, the great reach and depth of individual rights" (Ibid.).

Friedman does not believe that the social order is easily smashed. He has an explicitly organic view, even though he recognizes "the fallacy of extrapolation, expecting the future to be like the past, only more so" (Ibid.: 34). This makes him a reformer, not a revolutionary. It also helps explain why this tolerant scholar becomes somewhat intolerant of those who seem committed only to raising contradictions. To him, it is not difficult to do that. Nor is it at all clear that carefully-constructed deconstructions will somehow trickle into a torrent of radical change.

The history of legal change is very much Friedman's bailiwick. He has a sophisticated sense of the changes in the conditions of confinement in America's "iron grip of tradition in a rigid but comfortable prison of habits and norms." This helps Friedman elude common pitfalls. He does not cluck over a pattern of decline while romanticizing an earlier, more communal golden age, nor does he give way to despair. Friedman remains hopeful, despite the substantial congruence between his perspective and the bleaker point made by Grant Gilmore that "Law never creates society; society creates law. Law never makes society better; a better society will improve the law"15 (1966: 7).

Like Charles Beard, Friedman seems painfully aware that historians necessarily "see what is behind our eyes" (Nore, 1983: 156).

15 Grant Gilmore, "Law, Anarchy and History," 14 University of Chicago Law School Recond 1, 7 (Autumn, 1966). The gap between the Friedman's stillhopeful skepticism and Gilmore's darker vision is illustrated by Friedman's puzzled response to Gilmore's work on the demise of contracts where Friedman says, "Gilmore's chief reason for regretting the death of contract theory seemed nothing more than nostalgic sentimentality $\rightarrow$ sense of longing for the good old days, when scholars thought there was value in what they were do- 
Not even historians, who of all people should be aware of what Graham Wallas termed the "paradox of unintended consequences," are able to "force the iron gates of the future" (Ibid.: 156). Nevertheless, Beard and Friedman share a commitment to the historian's professional search for "history-as-actuality" (Nore, 1983: 167), to taking an active role in public affairs, and to trying to reach a broader public than do most historians by writing and teaching with verve and clarity. Beard and Friedman are both famous for stressing the impact of economic interests on legal materials, but both are also frequently mischaracterized as believers in determinism. As does Beard, Friedman acknowledges subjectivity but celebrates the "inquiring spirit of science" (Ibid.: 166) as "the chief safeguard against tyranny of authority, bureaucracy, and brute power (Ibid.).

I have placed Lawrence Friedman in the august company of Maitland and Beard. This association of a very funny, impish Jewish fellow from Chicago with two austere WASP giants is obviously problematic in numerous details. Yet Friedman belongs in their company. He, too, deserves recognition for the clarity of his thought, the richness of his scholarly understanding of ideas in social context, and the lucidity of his astonishingly prolific writing.

\section{CONCLUSION}

It may be whimsical to compare Friedman's work with the unmemorable films put out by Warner Brothers in the 1930s, but it is not entirely frivolous or inapt. Warner Brothers achieved fame and fortune for its gangster movies and newspaper films; social conscience films that attacked racism, fascism, inhumane prison systems and the like; "biopics" and more "classic" films. As Roddick put it: "[T] hose films marked both contemporary audiences in their attitude to the world and, in a different way, subsequent ideas of what is or is not a 'good' film"16 (1983: 254). The same might be said of Friedman's legal history work.

Moreover, as did Warner Brother's social conscience pictures

ing." (Lawrence Friedman, "American Legal History: Past and Present" 34 Journal of Legal Education 563 (1984)).

The tension between the bleakness of what we think we know about law and the idea that we hope to do better than we think we can through law was explored with particular insight by Arthur Leff. As Leff put it, in a memorial issue for Gilmore, Gilmore's bleak vision is probably right, but we are "lutists of the unknowable" who, on our way to those final defeats, may sometimes have "some beautiful innings." (Leff, "Law and . . .," 87 Yale Law Journal 1011 (1978)).

16 For important recent work on the linkage and tension between popular culture and formal legal images of law, see David Papke, Framing the Criminal: Crime, Cultural Work and the Lass of Critical Perspective (Hamden, 1987); Stewart Macaulay, "Images of Law in Everyday Life: The Lessons of School, Entertainment, and Spectator Sports," 21 Law \& Society Review 181 (1987); Anthony Chase, "Toward a Legal Theory of Popular Culture," 1986 Wisconsin Law Review 527. 
such as I am a Fugitive from a Chain Gang, Wild Boys of the Road, Angels with Dirty Faces, and Black Legion, Friedman also assumes "the strengths of a basically sound if temporarily problem-ridden society" (Ibid.: 128). He also keeps an eye on the bottom and middle of the social order. What today may seem idiosyncratic about Friedman's work is his quiet confidence in being able to communicate to a broad audience about social problems, combined with a skeptical optimist's leap of faith in America's social conscience. In a sense, Friedman's understanding of the powerful strains of resistance and self-interest in American history liberate him to battle for improvement. He knows of the "generous concealment of mirrors" (Schwartz, 1987: 95). He also knows we need mirrors to perceive what we must take as real, so we can do something to change it.

The considerable achievement of these social conscience films was their blend of story-telling craft and powerful condemnation of social outrages such as the chain gang system. Friedman's scholarship also operates with power and persuasiveness on many levels of craft and social consciousness. His massive outpouring of scholarship surely enlightens all kinds of readers. Friedman's work may even move people past personal reflections of what has passed.

AVIAM SOIFER is Professor of Law at Boston University. He holds B.A., M. Urban Studies, and J.D. degrees from Yale University. His recent publications include: " 'Toward a Generalized Notion of the Right to Form or Join an Association': An Essay for Tom Emerson," 38 Case Western Reserve Law Review 641 (1988) and "Status, Contract, and Promises Unkept," 96 Yale Law Journal 1916 (1987).

\section{REFERENCES}

ABEL, Richard L. (1973) "Law Books and Books about Law," 26 Stanford Law Review 175.

ALLEN, T.F.H., and Thomas B. STARR (1982) Hierarchy: Perspectives for Ecological Complexity. Chicago: Chicago University Press.

AUERBACH, Jerold (1976) Unequal Justice: Lawyers and Social Change in Modern America. New York: Oxford University Press.

BERGMAN, Andrew (1971) We're in the Money: Depression America and its Films. New York: New York University Press.

CHASE, Anthony (1986) "Toward a Legal Theory of Popular Culture," Wisconsin Law Review 527.

DIAMOND, Steve (1979) "Legal Realism and Historical Method: J. Willard Hurst and American Legal History," 77 Michigan Law Review 784.

DIGGINS, John (1982) "Power and Authority in American History: The Case of Charles A. Beard and His Critics," 87 American History Review 701.

ELTON, G.R. (1985) F.W. Maitland. New Haven, Conn.: Yale University Press.

ELY, J.W., Jr. (1973) “Book Review," 26 Vanderbilt Law Review, 1353. 
FRIEDMAN, Lawrence (1986) “A Search for Seizure: Pennsylvania v. Mahon in Context," 4 Law and History 1.

- (1985a) A History of American Law, 2nd ed. New York: Simon \& Schuster.

(1985b) Total Justice. New York: Russell Sage Foundation.

(1984a) Your Time Will Come: The Lavo of Age Discrimination and Mandatory Retirement. New York: Russell Sage Foundation (distributed by Basic Books).

(1984b) "Limited Monarchy: The Rise and Fall of Student Rights" in David L. Kirp and Donald N. Jensen, eds., School Days, Rule Days, The Legalization and Regulation of Education. London: Falmer Press.

- (1984c) "American Legal History: Past and Present" 34 Journal of Legal Education 563.

(1977) Law and Society: An Introduction. Englewood Cliffs, N.J.: Prentice Hall.

(1975) The Legal System. New York: Russell Sage Foundation.

(1969a) "Legal Culture and Social Development," 4 Law \& Society Review 29 .

._. (1969b) "Law Reform in Historical Perspective," 13 St. Louis Law Review 351 .

- (1969c) "Legal Culture and Social Development," 4 Law \& Society Review 29.

- (1968) Government and Slum Housing. A Century of Frustration. Chicago: Rand McNally and Company.

- (1967) "Legal Rules and the Process of Social Change," 19 Stanford Law Review 786.

L (1966) "On Legalistic Reasoning-A Footnote to Weber," Wisconsin Law Review 148.

- (1965) Contract Law in America: A Social and Economic Case Study. Madison: University of Wisconsin Press.

(1964) "Law and its Language," 33 George Washington Law Review 563.

FRIEDMAN, Lawrence, and Jack LADINSKY (1967) "Social Change and the Law of Industrial Accidents", 67 Columbia Law Review 50.

FRIEDMAN, Lawrence, and Robert V. PERCIVAL (1981) The Roots of Justice: Crime and Punishment in Alameda County, California, 1870-1910. Chapel Hill: University of North Carolina Press.

FRIEDMAN, Lawrence M., and S. WHEELER, B. CARTWRIGHT, R.A. KAGAN (1987) "Do the 'Haves' Come out Ahead? Winning and Losing in State Supreme Courts, 1870-1970," 21 Lavo \& Society Review 403.

GILMORE, Grant (1966) "Anarchy and History," 14 University of Chicago Law School Record 1.

GORDON, Robert (1987) "Unfreezing Legal Reality: Critical Approaches to Law," 15 Florida State University Law Review 195.

- (1984) "Critical Legal Histories," 36 Stanford Law Review 57.

(1982) "Holmes' Common Law As Legal and Social Science," 10 Hofstra Law Review 719.

- (1975) "J. Willard Hurst and the Common Law Tradition in American Legal Historiography," 10 Law \& Society Review 9.

HALL, David (1987) "On Common Ground: The Coherence of American Puritan Studies," 44 William and Mary Quarterly 3rd Series 193.

- (1979) "The World of Print and Collective Mentality in Seventh-Century New England," in John Higham and Paul K. Conkin, eds., New Directions in American Intellectual History. Baltimore: Johns Hopkins University Press.

HILL, William A. (1973) "Book Review," 50 North Dakota Law Review 147.

HOFSTADTER, Richard (1968) The Progressive Historians: Turner, Beard, Parrington. New York: Knopf.

HOLMES, Oliver Wendell (1953) Holmes-Laski Letters; The Correspondence of Mr. Justice Holmes and Harold J. Laski, 1916-1935, Mark De Wolfe Howe, ed. Cambridge, Mass: Harvard University Press.

HORWITZ, M.J. (1977) The Transformation of American Law. Cambridge, Mass: Harvard University Press.

Mass: Harvard University Press. History," 17 American Journal of Legal History 275. 
JOHNSON, Herbert (1974) "Survey of Legal Literature," 23 DePaul Law Review 1086.

KALMAN, Laura (1986) Legal Realism at Yale, 1927-1960. Chapel Hill: University of North Carolina Press.

LEFF, Arthur (1978) "Law and ...," 87 Yale Law Journal 1011.

LLEWELLYN, Karl (1934) "The Constitution as an Institution," 34 Columbia Law Review 1.

LURIE, J. (1973) "Book Review," 27 Rutgers Law Review 354.

MACAULAY, Stewart (1987) "Images of Law in Everyday Life: The Lessons of School, Entertainment, and Spectator Sports," 21 Law \& Society Review 181.

(1984), "Law and the Behavioral Sciences: Is There Any There There?, 6 Law \& Policy Quarterly 149.

MAITLAND, F.W., (1911) The Collected Papers of Frederic William Maitland, H.A.L. Fisher, ed. Buffalo: W.S. Hein.

MANN, Bruce (1987) Neighbors and Strangers: Law and Community in Early Connecticut. Chapel Hill: University of North Carolina.

MAZOR, Lester (1975) "Book Review," 60 Minnesota Law Review 147.

MILLER, Perry (1969) "The Life of the Mind in America: From the Revolution to the Civil War," 77 Yale Law Journal 1244.

MILSOM, S.F.C. (1982 for 1980), "F.W. Milsom," Master-Mind Lecture, in Proceedings of the British Academy. London: Oxford University Press.

MURPHY, Earl (1974) "Book Review," 26 Stanford Law Review 701.

NELSON, William (1974) "Book Review," 18 American Journal of Legal History 182.

NORE, Ellen (1983), Charles A. Beard: An Intellectual Biography. Carbondale: Southern Illinois University Press.

PAPKE, David (1987) Framing the Criminal: Crime, Cultural Work and the Loss of Critical Perspective, 1830-1900. Hamden: Archon Books.

PIERCE, C.A. (1975) "Book Review," 42 Tennessee Law Review 615.

PRESSER, Stephen (1973) "Book Review," 122 University of Pennsylvania Law Review, 217.

RODDICK, Nick (1983) A New Deal in Entertainment: Warner Brothers in the 1930's. London: British Film Institute.

RORTY, Richard (1979) Philosophy and the Mirror of Nature. Princeton: Princeton University Press.

SARTRE, Jean-Paul (1955) "No Exit," in No Exit and Three Other Plays. New York: Vintage Press.

SMITH, J.H. (1974) "Book Review," 24 University of Toronto Law Journal 108.

SCHLEGEL, John Henry (1984) "Notes toward an Intimate, Opinionated, and Affectionate History of the Conference on Critical Legal Studies," 36 Stanford Law Review 391.

- (1981) "American Legal Realism and Empirical Social Science: From the Yale Experience," 28 Buffalo Law Review 3.

(1980) "American Legal Realism and Empirical Social Science: The Singular Case of Underhill Moore," 29 Buffalo Law Review 2.

SCHWARTZ, Lynn Sharon (1987) "Killing the Bees," 2 Tikkun 92.

SPITZ, Stephen (1975) "Book Review," 36 Ohio State Law Journal 376.

TAYLOR, Peter (1985) The Old Forest and Other Tales. Garden City, N.Y.: The Dial Press.

TUCKER, Edwin (1973) "Book Review," 86 Harvard Law Review 1625.

TRUBEK, David (1984) "Where the Action Is: Critical Legal Studies and Empiricism," 36 Stanford Law Review 575.

TUSHNET, Mark (1977) "Perspectives on Development of American Law: A Critical Review of Friedman's A History of American Law," Wisconsin Law Review 81.

VANDEVELDE, Kenneth J. (1980) "The New Property of the Nineteenth Century: The Development of the Modern Concept of Property," 29 Buffalo Law Review 325.

WHITE, G. Edward (1986) "Looking at Holmes in the Mirror," 4 Law and History Review 439.

- (1973) "Book Review," 59 Virginia Law Review 1130. 
WHITFORD, William (1986) "Lowered Horizons: Implementation Research in a Post-CLS World," Wisconsin Law Review 75.

WOOD, Gordon (1979) "Intellectual History and Social Sciences," in John Higham and Paul K. Conkin, eds., New Directions in American Intellectual History. Baltimore: Johns Hopkins University Press.

WOODARD, Calvin in N.Y. Times, Feb. 16, 1986, sec. VIII, p. 31.

(1967) "History, Legal History, and Legal Education," 53 Virginia Law Review 89. 